\title{
The Post-Larval Stages of Ammodytes Species Captured during the Cruises of s.s. "Oithona" in Plymouth Waters in the Year 1919.
}

\author{
By
}

E. Ford, A.R.C.Sc.

Assistant Naturalist at the Plymouth Laboratory.

With two figures in the text.

THE post-larval stages of Ammodytes species captured in the young fish trawl and small-meshed nets during the cruises of s.s. Oithona in the year 1919 were separable into two well-defined series, $A$ and $B$ respectively. Details of the hauls of the trawl and nets with dates and localities are to be found on pages $210-212$ of Mr. R. S. Clark's account of the cruises in the present volume.

Considering the adult forms of Ammodytes known to occur in Plymouth waters, it is observed that Ammodytes lanceolatus, Lesauvage, and Ammodytes tobianus, L. are frequently met with, but no record is to hand at present of the occurrence of Ammodytes cicerellus, Rafin., although the latter has been taken frequently in the Atlantic. In regard to the larvæ and post-larvæ, none comparable to those assigned to A. cicerellus by Louis Fage $(1$, p. 17) have been described previously as.occurring in this district, nor have such forms revealed themselves in the material under present consideration.

In endeavouring to identify the post-larvæ of any species, a study of the characters of the adults is often of great help, but in the case of Ammodytes species the only features of the adult which seem to be of value in this respect are the number of vertebræand the relative length of the head to the total length of the body, and even so these characters, on account of the difficulty of determining them, are not so helpful as they would appear to be. Other characters have therefore to be sought for, and the following are those by which Series A and B have been distinguished :-

(A) Length of the upper jaw in relation to the diameter of the eye.

(B) Presence or absence of teeth-like structures in the upper jaw.

(C) Pigmentation.

(D) Number of vertebræ. 


\section{SERIES A.}

(A) Length of Upper Jaw in Relation to the Diameter of the EYe.

Table I gives the proportion of these characters for 51 individuals, and it will be seen that as the length increases the ratio $\left(\frac{j}{e}\right)$ increases for lengths up to $23 \mathrm{~mm}$. at least. A comparison with $\left(\frac{j}{\mathrm{e}}\right)$ for Series B (see p. 245) will show the significance of this character in distinguishing the two series.

\section{TABLE I.}

Length of Upper Jaw in Relation to the Diameter of the Eye in Series A.

$\begin{array}{ccc}\begin{array}{c}\text { Length of fish in } \\ \text { mm. groups. }\end{array} & \begin{array}{c}\text { Number of } \\ \text { specimens. }\end{array} & \begin{array}{c}\text { Length of upper jaw } \\ \text { Diameter of eye }\end{array}\left(\frac{\mathrm{j}}{\mathrm{e}}\right) \\ 5 & 1 & 1 \cdot 4 \\ 6 & 1 & 1 \cdot 4 \\ 7 & 1 & 1 \cdot 3 \\ 8 & 3 & 1 \cdot 7 \\ 9 & 3 & 1 \cdot 6 \\ 10 & 4 & 1 \cdot 8 \\ 11 & 5 & 1 \cdot 9 \\ 12 & 4 & 1 \cdot 9 \\ 13 & 3 & 1 \cdot 7 \\ 14 & 3 & 1 \cdot 9 \\ 15 & 2 & 1 \cdot 9 \\ 16 & 4 & 1 \cdot 9 \\ 17 & 1 & 2 \cdot 0 \\ 18 & 4 & 2 \cdot 0 \\ 19 & 5 & 2 \cdot 0 \\ 20 & 4 & 2 \cdot 1 \\ 23 & 1 & 2 \cdot 2 \\ 27 & 1 & 2 \cdot 1 \\ 34 & 1 & 1 \cdot 8\end{array}$

(B) Teeth-Like Structures in Upper JaW.

In every specimen of this series examined, with one possible exception of $5 \mathrm{~mm}$. in length, thorn-like teeth structures are present in the upper jaw which are easily visible under a low power of the microscope. Even in the possible exception referred to there is an indication of one tooth, but not conclusive enough for a definite assertion to be made. It is the only specimen of this length available for examination. 


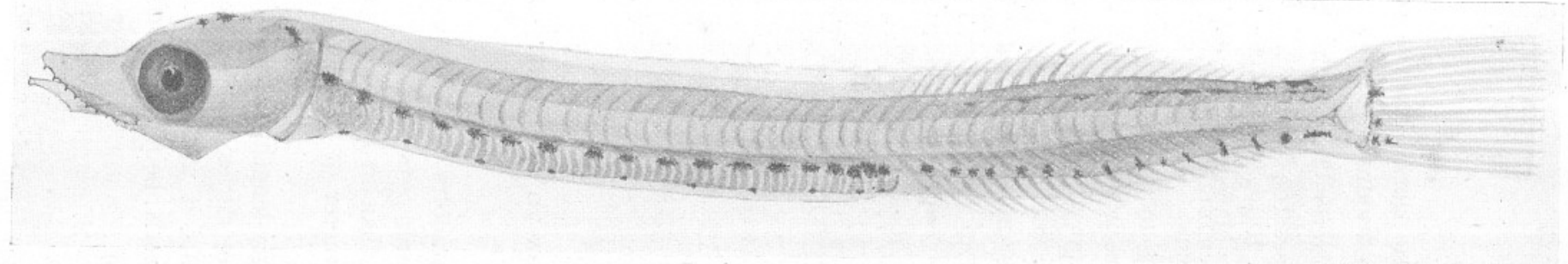

FIG. 1.-Ammodytes lanceolatus. Length $12 \mathrm{~mm}$. Oithona station, No. 24. 29th July, 1919. Del., E. Ford.

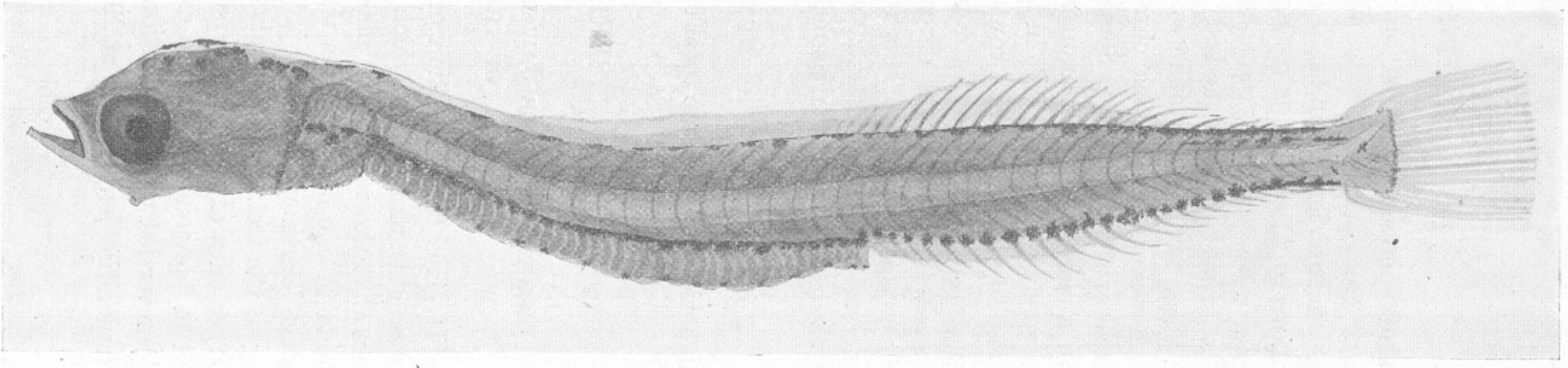

Frg. 2.-Ammodytes tobianus. Length $12.5 \mathrm{~mm}$. Oithona station, No. 2. 7th July, 1919, Del., E. ForD. 


\section{(C) Pigmentation.}

The black pigment situated on the extreme dorsal surface of the body is of great use in distinguishing the individuals of this series. From the shortest length up to $20 \mathrm{~mm}$. on average, with an occasional exception up to $22 \mathrm{~mm}$., it is restricted to two black stellate chromatophores which are strikingly persistent just in front of the root of the tail on the dorsal surface of the body. No other black pigment is present between these two chromatophores and the neck. Beyond $20 \mathrm{~mm}$. on average, however, other black chromatophores make their appearance at the base of the rays of the dorsal fin, commencing posteriorly, until at $27 \mathrm{~mm}$. a more or less continuous row is present which extends forward from the root of the tail to just in front of the anus.

At about $10 \mathrm{~mm}$. in length a row of black chromatophores commences at the posterior end above the dorsal surface of the vertebral column and beneath the two dorsal chromatophores referred to above, and gradually extends forward. This row is quite distinct from the subsequent one which commences at $20 \mathrm{~mm}$.

Fig. 1 illustrates the general pigment scheme of a post-larva of $12 \cdot 0 \mathrm{~mm}$.

\section{(D) The Number of Vertebræ.}

In this series the vertebræ total 68 or 69 .

\section{SERIES B.}

\section{(A) Length of Upper Jaw in Relation to the Diameter OF THE EYE.}

Table II gives the proportion of these characters for 17 individuals of the available material in which the measurements were obtainable. It is seen that the ratio $\left(\frac{j}{\mathrm{e}}\right)$ is much smaller than in Series A. It has been found in one or two cases that the diameter of the eye actually exceeds the length of the upper jaw.

Owing to the lack of individuals of the longer lengths in the material some larger ones of a-similar type to those of Series B from material collected in previous years were examined, and it was found that the ratio $\left(\frac{j}{e}\right)$ never led to any confusion with Series A, being always smaller for corresponding lengths. $\left(\frac{\mathrm{j}}{\mathrm{e}}\right.$ at $\left.29 \mathrm{~mm} .=1.5\right)$ 
TABLE II.

Length of Upper Jaw in Relation to the Diameter of the Eye IN SERIEs B.

Length of fish in
mm. groups.
6
7
8
9
10
11
12

\begin{tabular}{cc}
$\begin{array}{c}\text { Number of } \\
\text { specimens. }\end{array}$ & Length of uppe \\
\cline { 2 - 2 } 2 & $1 \cdot 0$ \\
4 & $1 \cdot 1$ \\
2 & $1 \cdot 2$ \\
3 & $1 \cdot 1$ \\
2 & $1 \cdot 0$ \\
2 & $1 \cdot 0$ \\
2 & $1 \cdot 1$
\end{tabular}

(B) Teeth-like Structures in Upper Jàw.

No individual of this series showed any signs of the presence of the conspicuous teeth so characteristic of Series A, nor have I been able to observe them in individuals from the material of the previous years of the same type as Series B, although the individuals of same type as Series A showed the teeth quite clearly.

\section{(C) Pigmentation.}

In specimens of the shorter lengths the black pigment dorsally consists of chromatophores along the base of the dorsal fin in the posterior region. It is always well marked, and rapidly assumes the form of a continuous row of chromatophores along the base of the dorsal fin. At between 9 and $10 \mathrm{~mm}$. in length this row has extended forward completely to the neck.

At about $9 \mathrm{~mm}$. an additional row appears above the dorsal surface of the vertebral column similar to that described in specimens of Series A.

In general, individuals of Series B seem to be pigmented much more heavily than those of Series A. (cf. Figs. 1 and 2).

\section{(D) The Number of Vertebræ.}

Difficulty has been experienced in this determination owing to the small size of the available specimens, but in the largest of Series B 65 vertebræ have been counted.

Considering Series A and B together, two other features present themselves which are quite useful in demonstrating further differences, 
although they are not so serviceable in practical identification as the ones already utilised :-

(1) The individuals of Series B appear to have their body structures such as tail and fin rays developed at shorter lengths than those of Series A.

(2) In the older stages from say $11 \mathrm{~mm}$. upwards, the head of individuals of Series A is longer relative to the length of the body than in those of Series B, but this difference is not so obvious in younger specimens.

On comparing the foregoing descriptions with those of the known investigators of Ammodytes species there seems no doubt that Series $\mathrm{A}$ and $\mathrm{B}$ are respectively $A$. lanceolatus and $A$. tobianus, and in support of this conclusion each of the distinguishing characters may be considered in turn to show to what degree the observations of Series A and B agree with or differ from the descriptions of these said investigators :-

\section{(1) Length of Upper Jaw in Relation to the Diameter OF THE EYE.}

Ehrenbaum (2, p. 190) remarks on the relatively longer upper jaw in $A$. lanceolatus than in A. tobianus in relation to the diameter of the eye at lengths exceeding $15 \mathrm{~mm}$., whereas in Series $\mathrm{A}$ the upper jaw is relatively longer at all observed lengths than in the corresponding lengths of Series B.

\section{(2) Teeth-Like Structures in Upper JaW.}

I have not been able to find any reference in available literature to the previous observation of the presence in $A$. lanceolatus and absence in A. tobianus of these structures, and this has caused me no little surprise in view of the celebrated observers who have studied these species. They are so clearly defined in the specimens of $A$. lanceolatus that I have examined, and equally indistinguishable in those of $A$. tobianus, that they must be pointed out as a very distinctive character.

\section{(3) Pigmentation.}

Both Ehrenbaum (3, p. 300 and 2, p. 189, Taf. VII, Figs. 70 and 71) and Louis Fage (1, p. 20) have emphasized the fact of the presence of the characteristic two black chromatophores on the dorsal surface of the body in $A$. lanceolatus. Ehrenbaum, however, has figured a post-larva of $12.5 \mathrm{~mm}$. (2, Taf. VII, Fig. 72) which has a continuous row of black 
pigment spots along the dorsal surface. This would appear to be different from the corresponding stage of Series A, but it is interesting to note, however, that Fage (1, p. 20) describes his corresponding specimens of A. lanceolatus as being comparable with this same figure of Ehrenbaum, with the exception that in each the dorsal pigment of the body is reduced to two precaudal chromatophores which are only visible in the youngest stages. It will be observed that the pigmentation scheme of Ehrenbaum's post-larva is very similar to that of Series B, and I would suggest that the specimen may be $A$. tobianus and not $A$. lanceolatus.

In regard to $A$. tobianus, the descriptions and figures given by Dantan (4, p. lxv, and Fig. 3) agree very well with the corresponding stages of Series B. Fage $(1$, p. 21) also gives a description of an individual of $14 \mathrm{~mm}$. which has a double uninterrupted row of brown pigment spots extending dorsally from the neck to the root of the tail-a similar feature to that presented in Series B. Dannevig (5, p. 29, Pl. III, Figs. 23 and 24) gives figures of $A$. tobianus which agree fairly well with Series B, although the pigment is not shown very clearly in the reproduction.

In regard to Ehrenbaum's description of the earlier stages of $A$. tobianus (3, pp. 298,299$)$ it will be noticed that the pigmentation is not described as of such heavy intensity as has been pointed out in Series B. In the latter, throughout the material all the individuals present a more intense pigment scheme than in Series A.

\section{(4) The Number of Vertebræ.}

The numbers observed in Series A and Series B are in agreement with those obtained by other workers, except that in Series B no individual was obtained with less than 65 vertebræ, a result no doubt due to the small number of specimens available for examination.

\section{(5) Length of Head in Relation to Body Length.}

Ehrenbaum (2, p. 190) remarks on the relatively longer head in A. lanceolatus. This has been pointed out in the case of the larger specimens of Series A.

In conclusion it is of interest to notice that the material from which the above observations have been made was obtained during the summer months, thus giving evidence that Ammodytes tobianus spawns in the Plymouth waters during this season of the year. It is not proposed, however, to discuss in this account the extent of the spawning period or periods of this species. 
E. FORD.

\section{REFERENCES.}

1. Fage, L., 1918. "Rept. Danish Oceanog. Expedt. 1908-10 to Mediterranean and Adjacent Seas." No. 4, Vol. II, A. 3, p. 16.

2. Ehrenbaum, E., 1904. "Wiss. Meeresunters. Abt. Helgoland." Bd. VI, pp. 184-194, Taf. VII.

3. Ehrenbaum, E., 1909. Nordisches Plankton. "Eier und Larven von Fischen." 2 Teil, p. 297.

4. Dantan, L., 1905. "Notes Ichtyologiques. Arch. Zool. Expt. Paris." N.R. 4e serie, T. III, p. lxv.

5. Dannevig, Alf., 1919. "Canadian Fisheries Expedition, 1914-15. Investigations in the Gulf of St. Lawrence and Atlantic Waters of Canada. Canadian Fish-Eggs and Larvæ," p. 29, and Plate III, Figs. 23 and 24. 